\title{
IDENTIFIKASI KECURANGAN LAPORAN KEUANGAN DENGAN FRAUD PENTAGON STUDI EMPIRIS BUMN TERDAFTAR DI BURSA EFEK INDONESIA
}

\author{
Oman Rusmana ${ }^{1 *}$, Hendra Tanjung ${ }^{1}$ \\ 1Program Pascasarjana Magister Akuntansi, Universitas Jenderal Soedirman, Indonesia \\ *Email corresponding author : satuhendratanjung@gmail.com
}

\begin{abstract}
Abstrak
Kecurangan laporan keuangan merupakan persoalan yang masih menjadi tema yang hangat untuk diperbincangkan, terlebih dengan mencuatnya kasus manipulasi laporan keuangan Garuda Indonesia tahun buku 2018. Tujuan dari penelitian ini adalah untuk mengidentifikasi potensi kecurangan laporan keuangan dengan menggunakan teori fraud pentagon. Teori fraud pentagon memiliki lima elemen risiko kecurangan yang dikembangkan dari teori fraud triangle Cressey 1953. Kelima elemen resiko tersebut adalah tekanan, kesempatan, rasionalisasi, kompetensi, dan arogansi. Pengujian dari elemen resiko fraud pentagon menggunakan variabel proksi yaitu stabilitas keuangan, tekanan eksternal, target keuangan, pengawasan yang tidak efektif, pergantian auditor, pergantian direktur, dan gambar CEO. Sementara itu, untuk variabel kecurangan laporan keuangan menggunakan variabel proksi manajemen laba yang diukur dengan metode Modifikasi Jones. Sampel yang digunakan adalah 13 perusahaan BUMN yang terdaftar di Bursa Efek Indonesia periode tahun 2015-2017. Data-data yang digunakan merupakan data sekunder yang diperoleh dari laman web perusahaan dan laman web Bursa Efek Indonesia. Metode analisis data menggunakan analisis regresi berganda, dimana pengolahannya dibantu oleh program SPSS 21. Hasil dari pengujian hipotesis menunjukkan bahwa variabel tekanan eksternal yang diukur dengan rasio leverage mempengaruhi kecurangan laporan keuangan. Sementara itu, variabel stabilitas keuangan yang diukur dengan rasio perubahan aset, variabel target keuangan yang diukur dengan ROA, variabel pengawasan yang tidak efektif yang diukur dengan rasio komisioner independen, variabel pergantian auditor, variabel pergantian direktur, dan variabel gambar CEO tidak terbukti mempengaruhi kecurangan laporan keuangan.
\end{abstract}

Kata kunci: Fraud Pentagon, Kecurangan, Manajemen Laba, Kecurangan Laporan Keuangan

\begin{abstract}
Fraudulent financial reporting is a problem that still warm theme to be discussed. Especially, with the emergence cases of financial statements manipulation of Garuda Indonesia fiscal in 2018. The purpose of this study is to identify potential fraudulent financial statements using the Pentagon fraud theory. Pentagon fraud theory has five elements of fraud risk developed from the 1953 Cressey fraud triangle theory. The five elements of risk are pressure, opportunity, rationalization, competence, and arrogance. Testing of the pentagon fraud risk elements uses proxy variables, namely financial stability, external pressure, financial targets, ineffective monitoring, change in auditor, change of director, and CEO image. Meanwhile, for the fraudulent financial reporting variable using proxy earnings management, variables measured by the Jones Modification method. The sample used was 13 state-owned companies listed on the Indonesia Stock Exchange in the period 2015-2017. The data used are secondary data obtained from the company's webpage and the Indonesia Stock Exchange webpage. The method of data analysis uses multiple regression analysis, where the processing is assisted by the SPSS 21 program. The results of hypothesis testing indicate that external pressure variables measured by leverage ratios affect fraudulent financial statements. Meanwhile, financial stability variables measured by asset change ratios, financial target variables measured by ROA, ineffective monitoring variables measured by the ratio of independent commissioners, change in auditor variables, change of director variables, and CEO image variables were not proven to affect fraudulent financial statements.
\end{abstract}

Key Words : Fraud Pentagon, Fraud, Earning Management, Fraudulent Financial Statements 


\section{PENDAHULUAN}

Laporan keuangan merupakan catatan atas aktivitas bisnis perusahaan yang dapat digunakan sebagai media untuk menilai kinerja. Laporan keuangan yang disajikan dengan unsur-unsur kualitatifnya yaitu mudah dipahami, andal, dapat dibandingkan, dan relevan akan menjadikan laporan keuangan tersebut memiliki fungsi yang maksimal (Sihombing \& Rahardjo, 2014). Salah satu fungsi laporan keuangan menurut FASB sebagaimana yang dituangkan dalam the statement of financial accounting concept (SFAC) nomor 1 adalah "penyedia informasi yang bermanfaat bagi investor potensial, kreditor dan pengguna lainnya untuk membuat keputusan investasi rasional, pemberian kredit, dan keputusan-keputusan serupa lainnya. Oleh sebab itu, disamping memenuhi unsur-unsur kualitatif laporan keuangan juga harus disajikan sesuai dengan ketentuan pernyataan standar akuntansi keuangan (PSAK). PSAK akan memberikan arah dan ketepatan dalam penyajian laporan keuangan serta akan mempengaruhi kualitas informasi yang dihasilkan (Santoso \& Surenggono, 2018). Untuk meyakinkan stakeholder bahwa laporan keuangan telah disajikan sesuai dengan ketentuan pernyataan standar akuntansi keuangan, maka laporan keuangan yang telah disusun oleh manajemen diaudit oleh akuntan publik. Namun, hasil audit yang dilakukan oleh akuntan publik tidak menjamin sepenuhnya bahwa laporan keuangan bebas dari kecurangan atau penipuan.

Perusahaan yang di kelola dalam kondisi pertumbuhan dan persaingan yang ketat tidak selalu menghasilkan kinerja yang diharapkan, disisi lain untuk tumbuh, berkembang dan mempertahankan keberlangsungan perusahaan, manajemen membutuhkan dana tambahan dari investor (Santoso \& Surenggono, 2018). Fakta ini terkadang membuat manajamen melakukan kecurangan untuk menutupi kinerja yang kurang baik tersebut agar memperoleh pendanaan baik dari investor maupun dari kreditor. Kecurangan laporan keuangan disamping memiliki motif untuk memperoleh kredit atau pendanaan dan menutupi kinerja yang buruk juga bertujuan untuk menjaga nilai saham (Rezaee, 2002). Salah satu contoh kasus kecurangan laporan keuangan yang paling fenomenal adalah kasus kecurangan yang dilakukan oleh Enron corporation sebuah perusahaan berskala multinasional. Kasus Enron ini menyeret akuntan publik Arthur Anderson yang bertanggungjawab atas audit laporan keuangan. Keberadaan Arthur Anderson dalam pusaran kasus Enron membuat reputasinya runtuh dan terlempar dari jajaran the big five akuntan publik. Contoh kasus lainnya yang terjadi didalam negeri adalah kasus rekayasa laporan keuangan PT. Garuda Indonesia tbk tahun buku 2018. Kasus ini juga menyeret akuntan publik yang melakukan audit atas laporan keuangan yaitu kantor akuntan publik Tanubrata, Sutanto, Fahmi, Bambang dan Rekan (Ananta, 2019). Atas kasus ini menteri keuangan Sri Mulyani menjatuhkan sanksi berupa pembekuan izin akuntan publik dan kantor akuntan publik selama 12 bulan (Kusuma, 2019). Kasus kecurangan yang terjadi pada Badan Usaha Miliki Negara tidak hanya terjadi pada PT. Garuda Indonesia tbk, tetapi juga terjadi pada PT. Waskita Karya tbk (Aji, 2019).

Kasus-kasus ini menambah daftar panjang BUMN yang memiliki masalah kecurangan baik itu manipulasi laporan keuangan maupun korupsi dan tentunya ini tidak dapat dilepaskan dari keterlibatan manajemen di dalamnya. Laporan ACFE tahun 2014 menunjukkan bahwa pelaku kecurangan $42 \%$ dilakukan oleh karyawan, 36\% dilakukan oleh manajer, dan 19\% dilakukan oleh pemilik perusahaan, hasil dari studi ini konsisten dari tahun ke tahun (Manurung \& Hardika, 2015). Hasil temuan ini sejalan dengan pernyataan Mintz \& Morris (2014) dan Rezaee (2002) yang menyatakan bahwa kasus-kasus kejahatan keuangan yang banyak dilakukan oleh berbagai perusahaan melibatkan manajemen didalamnya, seperti kasus kejahatan keuangan yang dilakukan Xerox, Sunbeam corporation, Livent corporation dll. 
Tujuan dari penelitian ini adalah melakukan investigasi kecurangan laporan keuangan perusahaan Badan Usaha Milik Negara (BUMN) yang terdaftar di Bursa Efek Indonesia periode 2015-2017 dengan menggunakan pendekatan fraud pentagon. Teori fraud pentagon dikembangkan oleh Jonathan T. Marks 2009 dengan melakukan pengembangan fraud triangle (Mangala \& Kumari, 2015). Fraud triangle terdiri dari tiga elemen resiko kecurangan yaitu tekanan (pressure), kesempatan (opportunity), dan rasionalisasi (rationalization). Jonathan T. Marks menambahkan dua elemen resiko kecurangan lainnya yaitu kompetensi (competence) dan arogansi (arrogance) (Marks, 2014). Namun, sebelum adanya teori fraud pentagon, Wolfe \& Hermanson (2004) telah mengembangkan teori fraud diamond. Teori fraud diamond ini juga dikembangkan dari teori fraud triangle Cressey dengan menambahkan satu elemen risiko kecurangan yaitu "kemampuan (capability)" (Wolfe \& Hermanson, 2004). Elemen risiko kecurangan "kemampuan" ini memiliki definisi dan makna yang sama dengan elemen resiko kecurangan "kompetensi" yang ada pada teori fraud pentagon, meskipun menggunakan kata yang berbeda (Yusof, Khair, \& Simon, 2015). Hal yang menarik yang mendorong ada penelitian ini adalah elemen risiko kecurangan "kompetensi/kemampuan" dan "arogansi" belum memiliki hasil-hasil penelitian yang konsisten pada penelitian Septriani \& Handayani (2018), Akbar (2017), Apriliana \& Agustina (2017), dan Husmawati, Septriani, Rosita, \& Handayani (2017). Disamping itu, menurut penulis kuantitas penelitian yang menggunakan teori fraud pentagon masih tergolong sedikit.

Variabel elemen-elemen resiko kecurangan tidak dapat diukur secara langsung (Apriliana \& Agustina, 2017; Sihombing \& Rahardjo, 2014; Skousen, Smith, \& Wright, 2009), maka pengukurannya dilakukan dengan menggunakan variabel proksi. Tekanan diproksikan dengan variabel stabilitas keuangan (financial stability), variabel tekanan eksternal (eksternal pressure), dan variabel target keuangan (financial targets). Kesempatan diproksikan dengan variabel pengawasan yang tidak efektif (ineffective monitoring), rasionalisasi diproksikan dengan variabel pergantian auditor (change in auditor), kompetensi diproksikan dengan variabel pergantian direktur (change of director), dan arogansi diproksikan dengan variabel gambar CEO (CEO picture). Pemilihan variabel-variabel proksi ini didasarkan pada tidak konsistennya temuan hasil dari variabel-variabel tersebut pada penelitian Indarto \& Ghozali (2016), Santoso \& Surenggono (2018), Manurung \& Hardika (2015), Sihombing \& Rahardjo (2014), Septriani \& Handayani (2018), Akbar (2017), Apriliana \& Agustina (2017), dan Husmawati et al (2017). Sementara itu, variabel kecurangan laporan keuangan (fraudulent financial reporting) diproksikan dengan variabel manajemen laba (Suyono, 2017). Pengukuran manajemen laba menggunakan akrual diskresioner model Modifikasi Jones.

\section{TINJAUAN PUSTAKA DAN PERUMUSAN HIPOTESIS}

\section{Teori Fraud Pentagon}

Teori Fraud Pentagon dikembangkan oleh Jonathan T. Marks 2009 (Mangala \& Kumari, 2015). Teori ini merupakan pengembangan dari teori Fraud Triangle Cressey 1953. Marks menilai bahwa dalam kondisi perkembangan lingkungan bisnis dan perubahan perilaku manusia selama 60 tahun terakhir, tiga elemen fraud triangle yaitu tekanan (pressure), kesempatan (opportunity), rasionalisasi (rationalization) sudah tidak memadai untuk menjelaskan perilaku kecurangan yang terjadi (Marks, 2014). Oleh sebab itu, Marks menambahkan dua elemen penting lainnya yaitu kompetensi (competence) dan arogansi (arrogance). Penambahan dua elemen ini memunculkan model baru dan cara berfikir baru yang kemudian dikenal dengan crowe fraud pentagon. 
Marks (2014) menjelaskan masing-masing elemen tersebut sebagai berikut: (1) tekanan (pressure) didefinisikan sebagai adanya motif untuk melakukan dan menyembunyikan kecurangan, (2) kesempatan (opportunity) merupakan adanya kesempatan untuk melakukan kecurangan yang diakibatkan oleh lemahnya pengendalian, (3) rasionalisasi (rasionalization) merupakan pembenaran atas kecurangan yang sedang direncanakan atau kecurangan yang telah terjadi, (4) kompetensi atau keterampilan (competence) merupakan kemampuan seseorang untuk mengesampingkan atau mengabaikan pengendalian internal, mengembangkan suatu strategi penyembunyian yang canggih, dan mengendalikan situasi sosial untuk keuntungannya dan/atau dengan menjualnya kepada orang lain, dan (5) arogansi (arrogance) merupakan sikap superioritas seseorang yang berkombinasi dengan hak atau keserakahan dan suatu keyakinan bahwa pengendalian internal tidak berlaku baginya. Masing-masing elemen atau kombinasi dari beberapa elemen dapat mendorong seseorang melakukan kecurangan atau penipuan. Namun, elemen kompetensi dan arogansi memiliki peran utama dalam mendorong terjadinya kecurangan atau penipuan (Marks, 2014).

\section{Manajemen Laba}

Manajemen laba (earning management) didefinisikan secara berbeda oleh beberapa ahli. Schipper, (1989) dalam Suyono (2017) mendefinisikan manajemen laba sebagai "intervensi yang disengaja dalam proses pelaporan eksternal, dengan tujuan memperoleh keuntungan pribadi", sedangkan Healy \& Wahlen (1999) mendefinisikan manajemen laba "ketika manajer menggunakan penilaian dalam laporan keuangan dan dalam menstrukturisasi transaksi untuk mengubah laporan keuangan untuk menyesatkan pemegang saham tentang kondisi kinerja ekonomi perusahaan, atau mempengaruhi hasil kontrak yang tergantung pada laporan angkaangka akuntansi". Definisi yang bernada positif disampaikan oleh McKee yang mendefinisikan manajemen laba dengan mengatakan bahwa manajemen laba merupakan sesuatu yang "wajar dan sah dalam membuat keputusan manajemen yang dimaksudkan untuk menjaga stabilitas capaian dan hasil-hasil keuangan yang dapat diprediksi" Mintz \& Morris (2014). McKee menggaris bawahi manajemen laba yang dilakukan dalam batas rasionalitas dan tidak melanggar etika. Meskipun McKee mendefinisikan manajemen laba secara positif, namun McKee tidak menggambarkan secara jelas batasan-batasan terkait "rasionalitas" dan "etika" yang disyaratkan.

Meskipun terdapat aneka ragam definisi manajemen laba, namun definisi yang paling sering digunakan dalam berbagai penelitian adalah manajemen laba merupakan manipulasi laporan keuangan yang dilakukan oleh para manajer berdasarkan penilaian mereka sendiri, dengan tujuan untuk membingungkan atau mengaburkan situasi ekonomi perusahaan yang sebenarnya kepada pengguna, atau untuk mempengaruhi kontrak yang mengandalkan laporan keuangan (Healy \& Wahlen, 1999).

\section{Kecurangan Laporan Keuangan}

Kecurangan, secara umum didefinisikan oleh Webster's New World Dictionary sebagai "the intentional deception to cause a person to give up property or some lawful right" (kecurangan yang disengaja yang menyebabkan seseorang menyerahkan harta atau hak yang sah) (Rezaee, 2002). Definisi tersebut memberikan dua kata kunci penting yaitu, pertama "kecurangan yang disengaja" yang berarti bahwa kecurangan dilakukan dalam kondisi sadar dan pelaku menyadari melakukan kecurangan dan kedua "menyebabkan" yang berarti bahwa kecurangan menimbulkan efek terhadap objek yang dicurangi.

The Association of Certified Fraud Examiners mendefinisikan kecurangan laporan keuangan sebagai "The intentional, deliberate, misstatement or omission of material facts, or accounting data which is misleading and, when considered with all the information made 
available, would cause the reader to change or alter his or her judgment or decision (yang disengaja, kesengajaan, salah saji atau kelalaian atas fakta material, atau data akuntansi yang menyesatkan, dan ketika dipertimbangkan dengan seluruh informasi yang tersedia, akan menyebabkan pembaca merubah penilaian atau keputusan) (Rezaee, 2002). Adanya kecurangan laporan keuangan akan menurunkan kualitas dan integritas informasi keuangan yang disajikan serta mempengaruhi para pihak yang memiliki kepentingan atas informasi yang disampaikan seperti investor dan kreditor. Selain investor dan kreditor, Auditor juga merupakan pihak yang paling dirugikan akibat adanya kecurangan laporan keuangan. Kerugian yang di alami oleh auditor adalah kejatuhan reputasi yang menyebabkan ketidakpercayaan. Oleh sebab itu, auditor harus memiliki mekanisme yang tepat untuk mendeteksi adanya kecurangan laporan keuangan.

\section{Model Penelitian}

Model proses investigasi kecurangan laporan keuangan dengan pendekatan fraud pentagon dapat dilihat pada gambar 1. Elemen-elemen fraud pentagon tidak dapat diukur secara langsung. Oleh kerena itu, pengukuran elemen fraud pentagon menggunakan variabel proksi. Tekanan (pressure) diukur dengan variabel stabilitas keuangan (financial stability), tekanan eksternal (external pressure), dan target keuangan (financial targets). Kesempatan (opportunity), rasionalisasi (rationalization), kompetensi (competence), dan arogansi (arogance) diukur dengan variabel proksi yang masing-masing adalah pengawasan yang tidak efektif (ineffective monitoring), pergantian auditor (change in auditor), pergantian direktur (change of director), dan Gambar CEO (CEO picture)

\section{Gambar 1. Model Penelitian}

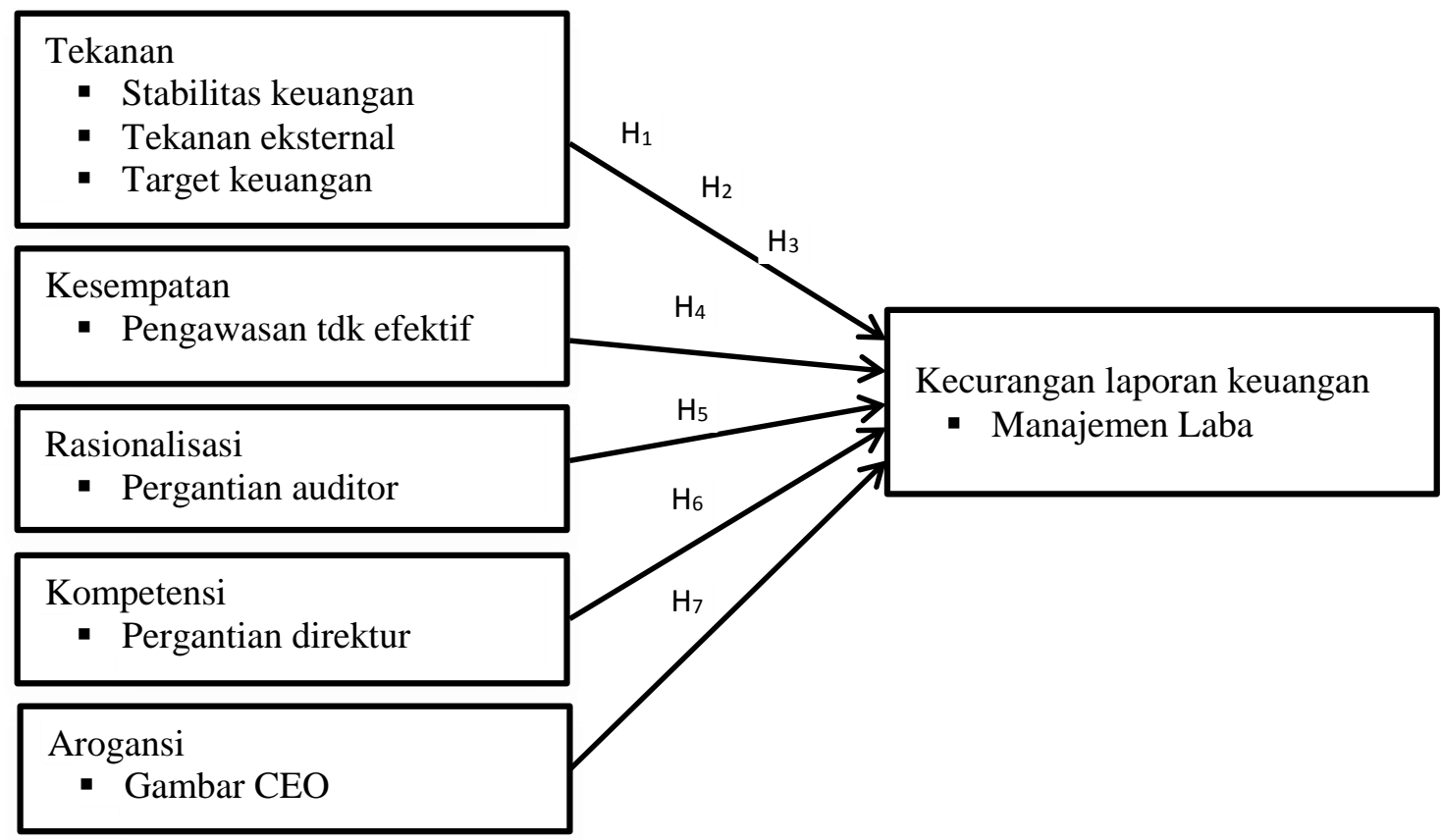

\section{Stabilitas Keuangan (Financial Stability)}

Stabilitas keuangan (financial stability) merupakan hal yang sangat penting bagi kehidupan perusahaan. Ketika stabilitas keuangan perusahaan berada dalam kondisi buruk, maka manajemen perusahaan akan melakukan usaha yang mungkin untuk memulihkan stabilitas keuangan agar terlihat baik (Santoso \& Surenggono, 2018). Hal yang sama juga diungkapkan oleh Skousen, Smith, \& Wright (2009) manajer akan dihadapkan pada tekanan untuk melakukan kecurangan ketika stabilitas keuangan dan/atau profitabilitas keuangan perusahaan terancam oleh kondisi ekonomi, industri, atau kondisi operasi perusahaan. Kondisi pertumbuhan yang berada dibawah rata-rata atau pertumbuhan yang terlalu cepat akan 
memaksa manajemen untuk memanipulasi laporan keuangan agar terlihat baik dan stabil (Loebbecke, Eining, \& Willingham, 1989) dalam Skousen, Smith, \& Wright (2009). Salah satu bentuk manipulasi yang dilakukan oleh manajemen berkaitan dengan pertumbuhan aset (Skousen, Smith, \& Wright, 2009). Oleh karena itu, rasio perubahan aset dapat dijadikan sebagai proksi dari variabel stabilitas keuangan. Dari uraian diatas, maka dirumuskan hipotesis sebagai berikut :

$\mathrm{H}_{1} \quad$ : Stabilitas keuangan dapat digunakan untuk mendeteksi kecurangan laporan keuangan.

\section{Tekanan Eksternal (External Pressure)}

Kemampuan untuk memenuhi persyaratan daftar tukar, membayar hutang atau memenuhi persyaratan hutang merupakan sumber-sumber dari adanya tekanan eksternal (Skousen, Smith, \& Wright, 2009). Oleh sebab itu, tekanan eksternal dapat diartikan sebagai tekanan yang dialami oleh manajemen untuk memenuhi persyaratan atau ketentuan dari pihak ketiga (Sihombing \& Rahardjo, 2014). Rasio leverage dijadikan sebagai proksi dari variabel tekanan eksternal (Skousen, Smith, \& Wright, 2009). Ketika rasio leverage tinggi berarti perusahaan memiliki tingkat hutang yang tinggi, sehingga menimbulkan resiko kredit yang tinggi. Kondisi leverage yang tinggi membuka peluang terjadinya gagal bayar. Untuk menghadapi kondisi ini, manajemen akan berusaha melakukan tindakan yang mungkin yang dapat menciptakan kondisi perusahaan terlihat tidak gagal bayar (Santoso \& Surenggono, 2018), seperti dengan memanfaatkan akrual diskresioner (Press \& Weintrop, 1990; Vermeer, 2003). Dari uraian diatas, maka dirumuskan hipotesis sebagai berikut :

$\mathrm{H}_{2} \quad$ : Tekanan eksternal dapat digunakan untuk mendeteksi kecurangan laporan keuangan.

\section{Target Keuangan (Financial Targets)}

Teori keagenan menggambarkan kontrak kerjasama antara manajemen sebagai agen dan pemegang saham sebagai prinsipal yang disebut dengan nexus of contract (Sihombing \& Rahardjo, 2014). Kontrak ini mencerminkan adanya perbedaan kepentingan antara manajemen dan pemegang saham. Pemegang saham menghendaki perusahaan dikelola secara baik agar memperoleh imbal balik yang tinggi, disamping itu manajemen berusaha mengelola perusahaan sebaik mungkin dengan motif utamanya untuk mendapatkan kompensasi tinggi berupa bonus atau kompensasi lainnya. Oleh sebab itu, dalam mengelola perusahaan manajemen akan dihadapkan pada target-target yang ditetapkan, namun disisi lain capaian-capaian kinerja perusahaan tidak selalu sesuai dengan yang diharapkan atau ditargetkan. Kondisi ini mendorong manajemen untuk melakukan aktivitas yang menyalahi ketentuan seperti melakukan manajemen laba untuk memperlihatkan bahwa kinerja perusahaan baik. Oleh sebab itu, perlu adanya indikator kinerja yang dapat menilai seberapa efisien operasional perusahaan. Indikator kinerja yang sering digunakan untuk mengukur seberapa efisien aktivitas operasional adalah return on asset/ROA (Skousen, Smith, \& Wright, 2009). Summers \& Sweeney (1998) menyampaikan bahwa terdapat perbedaan ROA secara signifikan antara perusahaan yang melakukan kecurangan dengan perusahaan yang tidak melakukan kecurangan. Penelitian yang dilakukan oleh Indarto \& Ghozali (2016) dan Santoso \& Surenggono (2018) menemukan bahwa ROA berpengaruh atau dapat dijadikan sebagai indikator untuk mendeteksi kecurangan laporan keuangan, namun hasil penelitian ini berbeda dengan temuan Skousen, Smith, \& Wright (2009) yang mengungkapkan bahwa ROA tidak memiliki pengaruh terhadap kecurangan laporan keuangan. Dari uraian diatas, maka dirumuskan hipotesis sebagai berikut:

$\mathrm{H}_{3} \quad$ : Target keuangan dapat digunakan untuk mendeteksi kecurangan laporan keuangan

\section{Pengawasan yang tidak efektif (Ineffective Monitoring)}

Lemahnya pengawasan merupakan salah satu penyebab terjadi kecurangan laporan keuangan. Lemahnya pengawasan memunculkan kesempatan kepada manajer atau agen untuk 
melakukan kecurangan. Penelitian yang dilakukan oleh Santoso \& Surenggono (2018) dan Manurung \& Hardika (2015) menemukan bahwa tidak efektifnya pengawasan dapat dijadikan sebagai indikator terjadinya kecurangan. Lemahnya pengawasan dapat dilihat dari ada tidaknya komisaris independen. Keberadaan dewan komisaris independen dapat menjadi alat untuk meningkatkan efektivitas pengawasan (Sihombing \& Rahardjo, 2014). Meningkatnya pengawasan akan dapat meminimalkan potensi kecurangan. Beasley (1999) menyampaikan bahwa keberadaan dewan komisaris yang berasal dari luar perusahaan dapat mencegah manajemen untuk melakukan kecurangan. Sementara itu, kecurangan laporan keuangan lebih sering terjadi pada perusahaan yang memiliki sedikit dewan komisaris yang berasal dari eksternal perusahaan (Skousen, Smith, \& Wright, 2009). Berdasarkan uraian diatas, maka dirumuskan hipotesis sebagai berikut:

$\mathrm{H}_{4} \quad$ : Pengawasan yang tidak efektif dapat digunakan untuk mendeteksi kecurangan laporan keuangan.

\section{Pergantian Auditor (Change in Auditor)}

Rasionalisasi merupakan elemen ketiga dari fraud treangle yang sulit untuk di ukur (Skousen, Smith, \& Wright, 2009). Marks (2014) mendefinisikan rasionalisasi sebagai pembenaran atas kecurangan yang sedang direncanakan atau yang sudah terjadi. Salah satu jembatan yang dapat menghubungkan antara rasionalisai dan kecurangan adalah adanya pergantian auditor (Lou \& Wang, 2009; Skousen et al., 2009). Loebbecke, Eining, \& Willingham (1989) dalam Skousen, Smith, \& Wright (2009) mengungkapkan bahwa pergantian auditor menyebabkan meningkatnya tingkat kejadian kegagalan audit dan ligitasi. Auditor merupakan pihak yang dianggap memiliki sikap independen untuk mengungkap kecurangan yang dilakukan perusahaan. Semakin banyak perusahaan yang mengganti auditor dapat dicurigai sebagai upaya perusahaan untuk menutupi kecurangan yang dilakukan (Apriliana \& Agustina, 2017). Penelitian yang dilakukan oleh Manurung \& Hardika (2015) menemukan bahwa pergantian auditor dapat dikaitkan dengan adanya kecurangan. Dari uraian diatas maka dirumuskan hipotesis sebagai berikut:

$\mathrm{H}_{5} \quad$ : Pergantian auditor dapat digunakan untuk mendeteksi kecurangan laporan keuangan

\section{Pergantian Direktur (Change of Director)}

Kompetensi (competence) merupakan elemen risiko kecurangan ke empat dari teori fraud pentagon yang diproksikan oleh variabel pergantian direktur. Pemberian nama elemen keempat ini berbeda dengan yang di cetuskan oleh Wolfe \& Hermanson (2004) dalam teori fraud diamond yaitu kemampuan (capability). Meskipun memiliki namanya yang berbeda tetapi memiliki makna yang sama (Yusof, Khair, \& Simon, 2015). Marks (2014) mendefinisikan kompetensi sebagai kemampuan seseorang untuk mengesampingkan atau mengabaikan pengendalian internal, mengembangkan suatu strategi penyembunyian yang canggih, dan mengendalikan situasi sosial untuk keuntungannya atau dengan menjualnya kepada orang lain. Terdapat enam ciri umum yang melekat pada elemen kompetensi yaitu, memiliki fungsi otoritas dalam organisasi, memiliki kecerdasan untuk memahami dan mengekploitasi situasi, memiliki kepercayaan diri, memiliki keterampilan untuk melakukan pemaksaaan, memiliki kemampuan untuk melakukan penipuan yang efektif, dan memiliki toleransi yang tinggi terhadap stress (Horwath, 2011). Pergantian direktur merupakan indikator adanya kecurangan (Apriliana \& Agustina, 2017; Saputra, 2016). Saputra (2016) mengungkapkan bahwa pergantian direktur tidak terlepas dari upaya politik dan serat dengan banyak kepentingan. Oleh sebab itu, pergantian direktur membuka peluang terjadinya kecurangan, dimana pergantian direktur akan menyebabkan terjadinya stress yang dapat dimanfaatkan oleh individu untuk melakukan kecurangan. Penelitian yang dilakukan oleh Husmawati et al., (2017) menunjukkan bahwa 
perganti direktur berpengaruh terhadap kecuranan laporan keuangan. Dari uraian diatas maka dirumuskan hipotesis sebagai berikut:

$\mathrm{H}_{6} \quad$ : Pergantian direktur dapat digunakan untuk mendeteksi kecurangan laporan keuangan.

\section{Gambar CEO}

Arogansi (arrogance) merupakan sikap superioritas seseorang yang berkombinasi dengan hak atau keserakahan dan suatu keyakinan bahwa pengendalian internal tidak berlaku baginya (Marks, 2014). Arogansi dalam teori fraud pentagon dapat dilihat dari jumlah gambar/foto CEO dalam laporan tahunan (Apriliana \& Agustina, 2017; Yusof et al., 2015). CEO perusahaan yang memiliki sikap arogansi akan memandang dirinya layaknya seorang selebritis, memiliki sikap yang angkuh bahwa mereka dapat menghindari pengendalian internal, memiliki sikap intimidasi, memiliki gaya manajemen autokratik, memiliki rasa ketakutan kehilangan posisi atau status (Horwath, 2011). Sikap-sikap tersebut akan membuka peluang terjadinya kecurangan, karena hal yang paling penting bagi CEO adalah bagaimana mempertahankan status dan posisi yang dimiliki. Penelitian yang dilakukan oleh Husmawati et al., (2017) dan Apriliana \& Agustina (2017) menunjukkan bahwa arogansi memiliki pengaruh terhadap kecurangan laporan keuangan. Namun, hasil ini berbeda dengan penelitian yang dilakukan oleh Akbar (2017). Dari uraian diatas maka dirumuskan hipotesis sebagai berikut:

$\mathrm{H}_{7} \quad$ : Gambar CEO dapat digunakan untuk mendeteksi kecurangan laporan keuangan

\section{METODE PENELITIAN}

\section{Populasi dan Sampel}

Populasi dalam penelitian ini adalah perusahaan Badan Usaha Milik Negara (BUMN) yang terdaftar di Bursa Efek Indonesia periode 2015-2017. BUMN merupakan entitas perusahaan yang unik, karena disatu disisi BUMN di tuntut untuk bersikap profesional dalam mengelola perusahaan, namun disisi lain dalam pengisian jabatan atau posisi penting di perusahaan tidak terlepas dari proses politik. Pengambilan sampel dilakukan dengan teknik pengambilan sampel bertujuan (purposive sampling). Penggunaan teknik puposive sampling dimaksudkan untuk mendapatkan data sampel yang sesuai dengan kriteria yang telah ditentukan (Hartono, 2013). Adapun kriteria sampel tersebut adalah (1) perusahaan terdaftar di Bursa Efek Indonesia dalam periode 2015-2017, (2) perusahaan tidak mengalami delisting dari Bursa Efek Indonesia selama periode 2015-2017, (3) perusahaan mempublikasikan laporan tahunan di website perusahaan atau website Bursa Efek Indonesia dan laporan keuangan disajikan dalam rupiah, dan (4) laporan tahunan dan laporan keuangan perusahaan menyajikan data-data yang sesuai dengan variabel penelitian. Dari 16 perusahaan BUMN yang terdaftar di Bursa Efek Indonesia, hanya 13 perusahaan BUMN yang memenuhi syarat yang ditetapkan. Dengan rentang waktu data penelitian selama tiga tahun yaitu 2015-2017, maka total keseluruhan sampel penelitian berjumlah 39 sampel.

Data-data yang digunakan dalam penelitian merupakan data sekunder. Data-data tersebut diperoleh dari laman website perusahaan dan laman website Bursa Efek Indonesia berupa data ICMD (Indonesia Capital Market Directory). Pengolahan data dilakukan dengan menggunakan program SPSS 21.

\section{Pengukuran Variabel}

\section{Variabel Dependen}

Variabel dependen dalam penelitian ini adalah kecurangan laporan keuangan (fraudulent financial reporting) yang diproksikan dengan variabel manajemen laba (earning management) Suyono (2017). Sementara itu, untuk pengukuran manajemen laba dilakukan dengan 
menggunakan akrual diskresioner (DACC) model modifikasi Jones. Adapun formula untuk mengukur akrual diskresioner adalah sebagai berikut:

$$
\begin{aligned}
& \mathrm{TACC}_{\text {it }}=\mathrm{NI}_{\mathrm{it}}-\mathrm{CFO}_{\mathrm{it}} \\
& \mathrm{NDA}_{\mathrm{it}}=\beta_{1}\left(\frac{1}{\text { Ait }-1}\right)+\beta_{2}\left(\frac{\Delta R E V i t}{\text { Ait }-1}-\frac{\Delta \text { RECit }}{\text { Ait }-1}\right)+\beta_{3}\left(\frac{\text { PPEit }}{\text { Ait }-1}\right) \\
& \text { DACC }_{\text {it }}=\frac{\text { TACit }}{\text { Ait }-1}-\mathrm{NDA}_{\mathrm{it}}
\end{aligned}
$$

\section{Keterangan :}

$\begin{array}{ll}\mathrm{TAC}_{\text {it }} & =\text { total akrual perusahaan i pada periode tahun } \mathrm{t} \\ \mathrm{NI}_{\text {it }} & =\text { laba bersih perusahaan i pada periode tahun } \mathrm{t} \\ \mathrm{CFO}_{\text {it }} & =\text { arus kas operasi perusahaan i pada periode tahun } \mathrm{t} \\ \mathrm{NDA}_{\text {it }} & =\text { nondiskresioner akrual perusahaan i pada periode tahun } \mathrm{t} \\ \text { Ait-1 } & =\text { total aset perusahaan i pada periode tahun } \mathrm{t}-1 \\ \Delta \mathrm{REVit} & =\text { perubahan pendapatan perusahaan i pada periode tahun } \mathrm{t} \\ \Delta \mathrm{RECit} & =\text { perubahan piutang perusahaan i pada periode tahun } \mathrm{t} \\ \mathrm{PPEit} & =\text { aset tetap perusahaan i pada periode } \mathrm{t} \\ \mathrm{DA}_{\text {it }} & =\text { akrual diskresioner perusahaan i pada periode tahun } \mathrm{t} \\ \beta_{1}, \beta_{2,} \beta_{3} & =\text { koefisien regresi }\end{array}$

\section{Variabel Independen}

Variabel independen yang digunakan dalam penelitian ini adalah stabilitas keuangan (financial stability) yang diukur dengan rasio perubahan total aset (ACHANGE), tekanan eksternal (external pressure) yang diukur dengan rasio leverage (LEV), target keuangan (financial targets) yang diukur dengan return on assets (ROA), pengawasan yang tidak efektif (ineffective monitoring) yang diukur dengan rasio komisaris independen (BDOUT), rasionalisasi (rationalization) yang diukur dengan pergantian auditor (CPA), kompetensi (competence) yang diukur dengan pergantian direktur (DCHANGE), dan arogansi (arrogance) diproksikan dengan gambar CEO (CEO picture). Adapun teknik pengukuran variabel independen dapat dilihat pada

\begin{tabular}{|c|c|c|}
\hline $\begin{array}{l}\text { Faktor-Faktor } \\
\text { Kecurangan }\end{array}$ & Variabel & Pengukuran Variabel \\
\hline \multirow{3}{*}{ Tekanan } & $\begin{array}{l}\text { Stabilitas } \\
\text { Keuangan } \\
\text { (ACHANGE) }\end{array}$ & $\begin{array}{l}\text { Stabilitas keuangan diukur dengan perubahan } \\
\text { total aktiva dengan formula sebagai berikut: } \\
=\frac{\text { Total aset } t-\text { Total } \text { Aset } t-1}{\text { Total aset } t-1}\end{array}$ \\
\hline & $\begin{array}{l}\text { Tekanan eksternal } \\
\text { (LEV) }\end{array}$ & $\begin{array}{l}\text { Tekanan eksternal diukur dengan rasio } \\
\text { leverage dengan formula sebagai berikut : } \\
=\frac{\text { Total Kewajiban }}{\text { Total } \text { Aset }}\end{array}$ \\
\hline & $\begin{array}{l}\text { Target keuangan } \\
\text { (ROA) }\end{array}$ & $\begin{array}{l}\text { Target keuangan diukur dengan return on aset } \\
\text { dengan formula sebagai berikut: } \\
=\frac{\text { Laba } \text { Bersih }}{\text { Total } \text { Aset }}\end{array}$ \\
\hline Kesempatan & $\begin{array}{l}\text { Pengawasan yang } \\
\text { tidak efektif } \\
\text { (BDOUT) }\end{array}$ & $\begin{array}{l}\text { Pengawasan yang tidak efektif diukur dengan } \\
\text { rasio komisaris independen terhadap total } \\
\text { dewan komisaris }\end{array}$ \\
\hline Rasionalisasi & $\begin{array}{l}\text { Pergantian } \\
\text { auditor (CPA) }\end{array}$ & $\begin{array}{l}\text { Pergantian auditor merupakan variabel } \\
\text { dummi, dimana } 1 \text { menunjukkan terdapat } \\
\text { pergantian auditor dan } 0 \text { menunjukkan tidak }\end{array}$ \\
\hline
\end{tabular}
tabel 1.

Tabel 1. Pengukuran variabel independen 
Identifikasi Kecurangan Laporan Keuangan Dengan Fraud Pentagon Studi Empiris Bumn Terdaftar Di

Bursa Efek Indonesia

\begin{tabular}{|l|l|l|}
\hline & & terdapat pergantian auditor \\
\hline Kompetensi & $\begin{array}{l}\text { Pergantian } \\
\text { direktur } \\
\text { (DCHANGE) }\end{array}$ & $\begin{array}{l}\text { Pergantian direktur merupakan variabel } \\
\text { dummi, dimana 1 menunjukkan terdapat } \\
\text { pergantian direktur dan 0 menunjukkan tidak } \\
\text { terdapat pergantian direktur }\end{array}$ \\
\hline Arogansi & $\begin{array}{l}\text { Gambar CEO } \\
\text { (CEOPIC) }\end{array}$ & $\begin{array}{l}\text { CEO Picture diukur dengan jumlah gambar/foto } \\
\text { CEO yang ditampilkan dalam laporan tahunan }\end{array}$ \\
\hline
\end{tabular}

Sumber : berbagai literatur

\section{Teknik Analisis Data}

Teknik analisis data yang digunakan untuk menguji hipotesis menggunakan analisis regresi berganda. Formula untuk analisis regresi berganda adalah sebagai berikut:

DACC $=\beta_{0}+\beta_{1}$ ACHANGE $+\beta_{2}$ LEV $+\beta_{3}$ ROA $+\beta_{4}$ BDOUT $+\beta_{5}$ CPA $+\beta_{6}$ DCHANGE $+\beta_{7}$ CEOPIC $+\varepsilon$

Keterangan :

$\begin{array}{ll}\beta_{0} & =\text { konstanta } \\ \beta_{1}, \beta_{2}, \beta_{3,}, \beta_{4}, \beta_{5}, \beta_{6}, \beta_{7} & =\text { koefisien regresi } \\ \text { DACC } & =\text { akrual diskresioner } \\ \text { ACHANGE } & =\text { perubahan total aset } \\ \text { LEV } & =\text { rasio levarage } \\ \text { ROA } & =\text { return on assets } \\ \text { BDOUT } & =\text { rasio komisioner independen } \\ \text { CPA } & =\text { perubahan kantor akuntan publik } \\ \text { DCHANGE } & =\text { perubahan direktur } \\ \text { CEOPIC } & =\text { jumlah foto CEO } \\ \varepsilon & =\text { error }\end{array}$

\section{HASIL DAN PEMBAHASAN}

\section{Statistik Deskriptif}

Statistik deskriptif merupakan gambaran data variabel penelitian yang terdiri dari nilai minimum, maksimum, rata-rata, dan standar deviasi. Hasil dari analisis statistik deskriptif dapat dilihat pada tabel 2 .

Tabel 2. Statistik Deskriptif

\begin{tabular}{lrrrrrrrr}
\hline & N & Range & Min & Max & Sum & Mean & $\begin{array}{c}\text { Std. } \\
\text { Deviation }\end{array}$ & Variance \\
\hline DACC & 39 & .44 & -.24 & .21 & -2.23 & -.0572 & .09727 & .009 \\
ACHANGE & 39 & 1.52 & -.10 & 1.42 & 11.35 & .2910 & .29279 & .086 \\
LEV & 39 & .70 & .10 & .79 & 20.63 & .5289 & .17121 & .029 \\
LNROA & 39 & .25 & -.05 & .21 & 2.04 & .0524 & .05455 & .003 \\
BDOUT & 39 & .40 & .20 & .60 & 14.28 & .3661 & .09297 & .009 \\
CPA & 39 & 1.00 & .00 & 1.00 & 15.00 & .3846 & .49286 & .243 \\
DCHANGE & 39 & 1.00 & .00 & 1.00 & 25.00 & .6410 & .48597 & .236 \\
CEOPIC & 39 & 2.00 & 3.00 & 5.00 & 140.00 & 3.5897 & .67738 & .459 \\
Valid N & 39 & & & & & & & \\
(listwise) & & & & & & & & \\
\hline
\end{tabular}

Dari 39 sampel penelitian, variabel akrual diskresioner (DACC) yang merupakan ukuran dari manajemen laba memiliki nilai total -2.23 , nilai maksimum 0.21 , nilai minimum -0.24 , selisih 0.44 , nilai rata-rata -0.0572 , standar deviasi 0.09727 , dan varian 0.009 . Variabel Stabilitas keuangan (ACHANGE) memiliki nilai total 11.35, nilai maksimal 1.42, nilai minimal -0.10, selisih 1.52, nilai rata-rata 0.2910 , standar deviasi 0.29279 , dan varian 0.086 . Variabel tekanan eksternal (LEV) memiliki nilai total 20.63, nilai maksimum 0.79 , nilai minimum 0.10 , selisih 0.70 , 
nilai rata-rata 0.5289 , standar deviasi 0.17121 , dan varian 0.029 . Variabel target keuangan (ROA) memiliki nilai total 2.04, nilai maksimum 0.21 , nilai minimum -0.05 , selisih 0.25 , nilai rata-rata 0.0524 , standar deviasi 0.05455 , dan varian 0.003 . Variabel pengawasan yang tidak efektif (BDOUT) memiliki nilai total 14.28, nilai maksimum 0.60, nilai minimum 0.20, selisih 0.40 , nilai rata-rata 0.3661, standar deviasi 0.09297, dan varian 0.009. Variabel pergantian auditor (CPA) memiliki nilai total 15.00 , nilai maksimum 1.00 , nilai minimum 0.00 , selisih 1.00 , nilai rata-rata 0.3846 , standar deviasi 0.49286 , dan varian 0.243 . Variabel pergantian direktur memiliki nilai total 25.00 , nilai maksimal 1.00, nilai minimal 0.00 , selisih 1.00 , nilai rata-rata 0.6410 , standar deviasi 0.48597 , dan varian 0.236 . Variabel gambar CEO (CEOPIC) memiliki nilai total 140, nilai maksimal 5.00, nilai minimal 3.00, selisih 2.00, nilai rata-rata 3.5897 , standar deviasi 0.67738 , dan varian 0.459 .

\section{Uji Hipotesis dan Pembahasan}

Tabel 3 menampilkan hasil uji koefisien determinan ( $\left.\mathrm{R}^{2}\right)$. Hasil uji yang digambarkan dari nilai adjusted R Square sebesar 0.265, menunjukkan bahwa variabel independen yaitu stabilitas keuangan, tekanan eksternal, target keuangan, pengawasan yang tidak efektif, pergantian auditor, pergantian direktur, dan gambar CEO mampu menjelaskan variabel dependen yaitu kecurangan laporan keuangan sebesar 26.5\%. 73.5\% lainnya dijelaskan oleh variabel-variabel lain yang tidak termasuk dalam model regresi.

Tabel. 3 Tes Koefisien Determinan $\left(\mathrm{R}^{2}\right)$

\begin{tabular}{ccccc}
\hline Model & $\mathbf{R}$ & R Square & $\begin{array}{c}\text { Adjusted R } \\
\text { Square }\end{array}$ & $\begin{array}{c}\text { Std. Error of the } \\
\text { Estimate }\end{array}$ \\
\hline $\mathbf{1}$ & $.642^{\mathrm{a}}$ & .412 & .265 & .07697 \\
\hline
\end{tabular}

a. Predictors: (Constant), CEOPIC, DCHANGE, LEV, CPA, BDOUT, LNROA, ACHANGE

Tabel 4 menampilkan hasil tes signifikansi simultan atau uji F. Nilai F sebesar 2.806 dengan tingkat signifikansi sebesar 0.024 yang berada dibawah nilai $\alpha(0.05)$, menunjukkan bahwa model regresi secara keseluruhan dapat digunakan untuk memprediksi variabel kecurangan laporan keuangan (DACC) atau dengan kata lain bahwa ke tujuh variabel independen secara keseluruhan memiliki pengaruh terhadap kecurangan laporan keuangan (DACC).

Tabel 4. Tes Signifikansi Simultan (Uji F) Anova $^{a}$

\begin{tabular}{llrrrrr}
\hline Model & $\begin{array}{c}\text { Sum of } \\
\text { Squares }\end{array}$ & Df & $\begin{array}{c}\text { Mean } \\
\text { Square }\end{array}$ & F & $\begin{array}{c}\text { Sig. } \\
(\boldsymbol{\alpha}=\mathbf{0 . 0 5})\end{array}$ \\
\hline $\mathbf{1}$ & Regression & .116 & 7 & .017 & 2.806 & $.024 \mathrm{~b}$ \\
& Residual & .166 & 28 & .006 & & \\
& Total & .282 & 35 & & & \\
\hline
\end{tabular}

a. Dependent Variable: DACC

b. Predictors: (Constant), CEOPIC, DCHANGE, LEV, CPA, BDOUT, LNROA, ACHANGE

Tabel 5 menampilkan hasil uji parsial masing-masing variabel independen terhadap variabel dependen. Hipotesis 1 menyatakan bahwa variabel stabilitas keuangan dapat digunakan untuk mendeteksi kecurangan laporan keuangan. Hasil uji t stabilitas keuangan (ACHANGE) memiliki nilai $\mathrm{t}-0.527$ dengan tingkat signifikansi 0.603. Nilai signifikansi 0.603 lebih besar dari nilai $\alpha(0.05)$, dengan demikian $\mathrm{H}_{1}$ ditolak. Hasil ini mencerminkan bahwa stabilitas keuangan yang diukur oleh variabel rasio perubahan nilai aset tidak mutlak mengindikasikan adanya kecurangan laporan keuangan. Perubahan kenaikan atau penurunan nilai aset dapat diakibatkan oleh adanya implementasi metode nilai wajar dalam pencatatan nilai aset atau juga dapat disebabkan oleh adanya revaluasi nilai aset yang dapat mengakibatkan nilai aset meningkat atau menurun. Disamping itu, kondisi stabilitas keuangan perusahaan yang kurang baik tidak memotivasi manajemen untuk melakukan kecurangan dengan menaikkan nilai aset. Hal ini cukup beralasan, karena menaikkan nilai aset dengan melakukan kecurangan akan membuat perusahaan berada dalam kesulitan dimasa depan dengan sulitnya perusahaan untuk mendapatkan tambahan dana untuk keberlangsungan perusahaan baik itu dari investor maupun dari kreditor. Hasil penelitian ini sejalan dengan hasil penelitian Santoso \& Surenggono 
(2018) dan Norbarani \& Rahardjo (2012). Namun, hasil penelitian ini berbeda dengan hasil penelitian Skousen, Smith, \& Wright (2009) yang menyatakan bahwa terdapat keterkaitan antara stabilitas keuangan dengan kecurangan laporan keuangan.

Tabel 5. Tes Signifikansi (Uji t)

Coefficients ${ }^{\mathrm{a}}$

\begin{tabular}{llccccc}
\hline \multirow{2}{*}{ Model } & \multicolumn{2}{c}{$\begin{array}{c}\text { Unstandardized } \\
\text { Coefficients }\end{array}$} & $\begin{array}{c}\text { Standardized } \\
\text { Coefficients }\end{array}$ & T & Sig \\
\hline \multirow{1}{*}{$\mathbf{1}$} & (Constant) & -.315 & Std. Error & Beta & & \\
\hline & ACHANGE & -.036 & .145 & & -2.177 & .038 \\
& LEV & .353 & .109 & -.119 & -.527 & .603 \\
& LNROA & .024 & .014 & .690 & 3.243 & .003 \\
& BDOUT & .173 & .150 & .277 & 1.728 & .095 \\
& CPA & -.006 & .027 & .185 & 1.149 & .260 \\
& DCHANGE & -.006 & .029 & -.036 & -.234 & .816 \\
& CEOPIC & .029 & .024 & -.033 & -.212 & .834 \\
\hline
\end{tabular}

a. Dependent Variable: DACC

Hipotesis 2 menyatakan bahwa variabel tekanan eksternal dapat digunakan untuk mendeteksi kecurangan laporan keuangan. Hasil uji t tekanan eksternal (LEV) memiliki nilai $t$ 3.243 dengan tingkat signifikansi 0.003. Nilai signifikansi ini lebih kecil dari nilai $\alpha(0.05)$, dengan demikian $\mathrm{H}_{2}$ diterima. Makna dari diterimanya $\mathrm{H}_{2}$ adalah tekanan eksternal yang diukur dengan rasio leverage dapat mengindikasikan terjadinya kecurangan laporan keuangan. Perusahaan yang memiliki jumlah hutang yang banyak atau terus menerus melakukan hutang sangat mungkin melakukan kecurangan laporan keuangan, karena untuk mendapatkan tambahan hutang baik itu dari investor maupun kreditor, pasti pihak investor dan kreditor melihat sejauh mana kemampuan perusahaan dalam mengembalikan dana yang diinvestasikan atau dana yang dipinjamkan. Disinilah perusahaan memungkin melakukan kecurangan dengan memanipulasi laporan keuangan sehingga kinerja perusahaan dan prospek perusahaan terlihat baik dan tentunya hal ini akan dapat memberikan keyakinan kepada investor dan kreditor bahwa perusahaan mampu untuk melakukan pembayaran hutang. Hasil penelitian ini didukung oleh hasil penelitian yang dilakukan Skousen, Smith, \& Wright (2009), Indarto \& Ghozali (2016), dan Santoso \& Surenggono (2018). Namun, hasil penelitian ini berbeda dengan hasil penelitian Septriani \& Handayani (2018) yang menyatakan sebaliknya.

Hipotesis 3 menyatakan bahwa variabel target keuangan dapat digunakan untuk mendeteksi kecurangan laporan keuangan. Hasil uji target keuangan (LNROA) memiliki nilai t 1.728 dengan tingkat signifikansi 0.095. Nilai signifikansi ini berada diatas nilai $\alpha(0.05)$, oleh sebab itu $\mathrm{H}_{3}$ ditolak. Hasil ini mengindikasikan bahwa target keuangan yang di ukur dengan $\mathrm{ROA}$ tidak serta merta mengindikasikan adanya kecurangan laporan keuangan. Perusahaan yang memiliki ROA yang tinggi pada saat ini, tentunya akan memotivasi perusahaan tersebut untuk meningkatkan ROA nya pada periode berikutnya. Disamping itu, kondisi perekonomian yang tidak stabil dan tingkat persaingan bisnis yang sengit juga dapat mempengaruhi tingkat profitabilitas perusahaan yang pada akhirnya akan menyebabkan nilai ROA menjadi rendah. Hasil penelitian ini sejalan dengan hasil penelitian Skousen, Smith, \& Wright (2009), Sihombing \& Rahardjo (2014), Apriliana \& Agustina (2017), dan Husmawati et al., (2017).

Hipotesis 4 menyatakan bahwa variabel pengawasan yang tidak efektif dapat digunakan untuk mendeteksi kecurangan laporan keuangan. Hasil uji variabel pengawasan yang tidak efektif menghasilkan nilai t 1.149 dengan tingkat signifikansi 0.260. Nilai signifikansi ini berada diatas nilai $\alpha(0.05)$, dengan demikian $\mathrm{H}_{4}$ ditolak. Keberadaan komisaris independen yang menjadi alat ukur variabel pengawasan yang tidak efektif sejatinya hadir untuk meningkatkan kinerja perusahaan dan juga untuk menjaga perusahaan agar dioperasikan atau di jalankan secara benar. Namun demikian, Sihombing (2014) mengungkapkan bahwa keberadaan komisaris independen tidak ada artinya apabila terdapat intervensi, sehingga komisaris 
independen tidak dapat memerankan fungsinya sebagaimana mestinya. Dalam perusahaan BUMN sangat mungkin terjadinya intervensi, mengingat bahwa BUMN berada dibawah kementerian BUMN. Hasil penelitian ini sejalan dengan hasil penelitian yang dilakukan oleh Akbar (2017), Apriliana \& Agustina (2017), Husmawati et al., (2017), dan Sihombing \& Rahardjo (2014).

Hipotesis 5 menyatakan bahwa variabel pergantian auditor dapat digunakan untuk mendeteksi kecurangan laporan keuangan. Hasil uji variabel pergantian auditor menghasilkan nilai t -0.234 dengan tingkat signifikansi sebesar 0.816 . Nilai signifikansi ini lebih besar dari nilai $\alpha(0.05)$, dengan demikian $\mathrm{H}_{5}$ ditolak. Hasil ini dapat disimpulkan bahwa pergantian auditor tidak dapat digunakan untuk mendeteksi kecurangan laporan keuangan atau dengan kata lain pergantian auditor tidak berpengaruh terhadap kecurangan laporan keuangan. Pergantian auditor dapat disebabkan oleh ketidakpuasan perusahaan dengan kinerja auditor yang melakukan audit dan juga dapat disebabkan oleh kebijakan kantor akuntan publik itu sendiri. Kantor akuntan publik yang ingin menjaga kepercayaan publik dengan menjaga independensi tentunya akan menerapkan mekanisme yang ketat dalam menugaskan auditor. Ketika perusahaan merasa tidak puas dengan kinerja auditor yang melakukan audit, perusahaan dapat mengajukan permintaan untuk mengganti auditor. Permintaan ini bisa terjadi ketika perusahaan sedang berusaha untuk memperbaiki kinerjanya dengan melihat hasil audit yang berkualitas. Namun, apabila perusahaan mengganti auditor dengan alasan bahwa auditor tidak dapat diajak bekerja sama untuk memanipulasi laporan keuangan sesuai dengan yang diinginkan perusahaan, maka tingkat kecurangan laporan keuangan akan meningkat (Stice, 1991) dalam Sihombing \& Rahardjo (2014). Hasil penelitian ini sejalan dengan hasil penelitian yang dilakukan Septriani \& Handayani (2018), Sihombing \& Rahardjo (2014), dan Akbar (2017). Hasil yang berbeda ditunjukkan oleh penelitian Husmawati et al., (2017) yang menyatakan bahwa pergantian auditor memiliki pengaruh terhadap kecurangan laporan keuangan.

Hipotesis 6 menyatakan bahwa variabel pergantian direktur dapat digunakan untuk mendeteksi kecurangan laporan keuangan. Nilai t variabel pergantian direktur berada pada nilai -0.212 dengan tingkat signifikansi 0.834 yang berada di atas nilai $\alpha(0.05)$, dengan demikian $\mathrm{H}_{6}$ ditolak. Dapat disimpulkan bahwa pergantian direktur tidak berpengaruh terhadap kecurangan laporan keuangan. Hal ini dapat terjadi, karena perusahaan mengganti direktur dengan maksud dan tujuan untuk memperbaiki kinerja perusahaan sebagaimana yang diungkapkan oleh Wolfe \& Hermanson (2004). Hasil penelitian ini sejalan dengan penelitian Sihombing \& Rahardjo (2014), Septriani \& Handayani (2018), Akbar (2017), dan Apriliana \& Agustina (2017).

Hipotesis 7 menyatakan bahwa gambar CEO dapat digunakan untuk mendeteksi kecurangan laporan keuangan. Hasil pengujian variabel gambar CEO menunjukkan nilai t sebesar 1.223 dengan tingkat signifikansi 0.232. Nilai signifikansi ini berada diatas nilai $\alpha(0.05)$, dengan demikian $\mathrm{H}_{7}$ ditolak atau dengan kata lain bahwa gambar CEO tidak berpengaruh terhadap kecurangan laporan keuangan. Hasil ini dapat disebabkan oleh tidak signifikannya jumlah gambar CEO yang ditampilkan dalam laporan tahunan perusahaan, sehingga tidak mencerminkan sikap arogansi dan mentalitas selebritis seperti yang sampaikan oleh Horwath (2011). Hasil penelitian ini sejalan dengan hasil penelitian Septriani \& Handayani (2018) dan Akbar (2017). Namun hasil penelitian ini berbeda dengan hasil penelitian Apriliana \& Agustina (2017) dan Husmawati et al., (2017) yang menyatakan bahwa gambar CEO memiliki pengaruh terhadap kecurangan laporan keuangan.

\section{KESIMPULAN, KETERBATASAN DAN SARAN}

Tujuan dari penelitian ini untuk membuktikan bahwa variabel stabilitas keuangan, tekanan eksternal, target keuangan, pengawasan yang tidak efektif, pergantian auditor, pergantian direktur, dan gambar CEO dapat digunakan untuk mendeteksi kecurangan laporan keuangan atau dengan makna lain bahwa variabel-variabel tersebut memiliki pengaruh terhadap kecurangan laporan keuangan. Hasil pengujian yang dilakukan pada sampel perusahaan BUMN menunjukkan bahwa hanya variabel tekanan eksternal yang memiliki pengaruh terhadap kecurangan laporan keuangan. Sementara itu, variabel stabilitas keuangan, 
target keuangan, pengawasan yang tidak efektif, pergantian auditor, pergantian direktur dan gambar CEO gagal dibuktikan mempengaruhi kecurangan laporan keuangan.

Penelitian ini memiliki beberapa keterbatasan, pertama sampel dalam penelitian ini hanya perusahaan BUMN sehingga sampel yang dilibatkan dalam penelitian jumlahnya kecil. Disamping itu, perusahaan BUMN yang menjadi sampel sangat mungkin memiliki karakteristik yang berbeda yang dapat mempengaruhi hasil penelitian. Kedua, rentang waktu data penelitian yang digunakan tergolong singkat yaitu hanya tiga tahun dari tahun 2015 sampai dengan 2017.

Penelitian yang akan datang mempertimbangkan beberapa hal, pertama menambah rentang waktu penelitian selama lima tahun atau lebih. Kedua, penelitian berikutnya dapat menggunakan sampel yang sama dengan rentang waktu yang lebih lama, tetapi menggunakan metode untuk mengukur manajemen laba dengan metode lain seperti metode Beneish M-Score, Metode F-score, metode Stuben atau metode-metode lainnya. Ketiga, penelitian berikutnya menggunakan sampel yang berbeda dari penelitian ini tetapi sampel tersebut memiliki karakteristik yang sama.

\section{DAFTAR PUSTAKA}

Aji, M. R. (2019). Kasus Korupsi PT Waskita Karya, KPK Cegah 5 Orang ke Luar Negeri. Retrieved July 10, 2019, from https://nasional.tempo.co/read/1156434/kasus-korupsi-pt-waskita-karya-kpk-cegah5-orang-ke-luar-negeri/full\&view=ok

Akbar, T. (2017). The Determination of Fraudulent Financial Reporting Causes by Using Pentagon Theory On Manufacturing Companies In Indonesia. International Journal of Business, Economics and Law, 14(December), 106-113.

Ananta, Y. (2019). BPK Temukan Banyak Rekayasa dalam Lapkeu Garuda 2018. Retrieved July 6, 2019, from https://www.cnbcindonesia.com/market/20190626090139-17-80654/bpk-temukan-banyakrekayasa-dalam-lapkeu-garuda-2018

Apriliana, S., \& Agustina, L. (2017). The Analysis of Fraudulent Financial Reporting Determinant through Fraud Pentagon Approach. Jurnal Dinamika Akuntansi, 9(2), 154-165. https://doi.org/10.15294/jda.v7i1.4036

Beasley, M. S. (1999). COSO's New Fraud Study: What It Means for CPAs. Journal of Accountancy. Retrieved from https://www.journalofaccountancy.com/issues/1999/may/profiss.html

Hartono, J. (2013). Metodologi Penelitian Bisnis Salah Kaprah dan Pengalaman-Pengalaman (Pertama). BPFE-YOGYAKARTA.

Healy, P. M., \& Wahlen, J. M. (1999). A Review of the Earnings Management Literature and Its. Accounting Horizons, 13(4), 365-383.

Horwath, C. (2011). Why the Fraud Triangle is No Longer Enough, 55. Retrieved from www.crowehorwath.com

Husmawati, P., Septriani, Y., Rosita, I., \& Handayani, D. (2017). Fraud Pentagon Analysis in Assessing the Likelihood of Fraudulent Financial Statement ( Study on Manufacturing Firms Listed in Bursa Efek Indonesia Period 2013-2016 ). International Conference of Applied Science on Engineering, Business, Linguistics and Information Technology (ICo-ASCNITech), (13-15 October), 45-51.

Indarto, S. L., \& Ghozali, I. (2016). Fraud Diamond: Detection Analysis on the Fraudulent Financial Reporting. Risk Governance and Control: Financial Markets \& Institutions, 6(4), 116-123. https://doi.org/10.22495/rcgv6i4c1art1

Kusuma, H. (2019). Sri Mulyani Bekukan Akuntan Publik Kasner Sirumapea Mulai 27 Juli. Retrieved July 6, 2019, from https://finance.detik.com/bursa-dan-valas/d-4603707/sri-mulyani-bekukan-akuntanpublik-kasner-sirumapea-mulai-27-juli

Loebbecke, J., Eining, M., \& Willingham, J. (1989). Auditors' experience with material irregularities: Frequency, nature, and detestability. Auditing: A Journal of Practice \& Theory, 9 (Fall), 1-28.

Lou, Y.-I., \& Wang, M.-L. (2009). Fraud Risk Factor Of The Fraud Triangle Assessing The Likelihood of Fraudulent Financial Reporting. Journal of Business \& Economics Research (JBER), 7(2), 61-78. https://doi.org/10.19030/jber.v7i2.2262 
Mangala, D., \& Kumari, P. (2015). Corporate Fraud Prevention and Detection: Revisiting the Literature. Journal of Commerce and Accounting Research, 4(1). https://doi.org/10.21863/jcar/2015.4.1.006

Manurung, D. T. H., \& Hardika, A. L. (2015). Analysis of factors that influence financial statement fraud in the perspective fraud diamond: Empirical study on banking companies listed on the Indonesia Stock Exchange year 2012 to 2014. International Conference on Accounting Studies (ICAS), (August).

Retrieved from www.icas.my

Marks, J. T. (2014). Playing offense in a high-risk environment. Crowe Horwath, 94(8), 14. Retrieved from http://0-

search.ebscohost.com.wam.city.ac.uk/login.aspx?direct=true \&db=bth\&AN=44618947\&site=ehostlive

Mintz, S. M., \& Morris, R. E. (2014). Ethical Obligations and Decision Making in Accounting (3rd ed.). McGraw-Hill.

Norbarani, L., \& Rahardjo, S. N. (2012). Pendeteksian Kecurangan Laporan Keuangan Dengan Analisis Fraud Triangle yang Diadopsi dalam SAS No.99. Acta Anaesthesiologica Scandinavica, 29(4), 69. https://doi.org/10.1111/j.1399-6576.1985.tb02224.x

Press, E., \& Weintrop, J. (1990). Accounting constraints in public and private debt agreements: Their association with leverage and impact on accounting choice. Journal of Accounting and Economics, 12, 65-95.

Rezaee, Z. (2002). Financial Statement Fraud Prevention and Detection. John Wiley \& Sons, Inc. New York: John Wiley \& Sons, Inc. https://doi.org/10.1201/b16665-6

Santoso, N. T., \& Surenggono. (2018). Predicting Financial Statement Fraud with Fraud Diamond Model of Manufacturing Companies Listed in Indonesia. State-of-the-Art Theories and Empirical Evidence, 151163. https://doi.org/10.1007/978-981-10-6926-0_9

Saputra, R. A. (2016). Pengaruh Fraud Indicators terhadap Fraudulent Financial Statement (Studi Empiris pada Perusahaan yang Listed di BEI Tahun 2013-2015.

Schipper, K. (1989). Commentary on Earnings Management. Accounting Horizons, 91-102.

Septriani, Y., \& Handayani, D. (2018). Mendeteksi Kecurangan Laporan Keuangan dengan Analisis Fraud Pentagon. Jurnal Akuntansi Keuangan Dan Bisnis, 11(1), 11-23.

Sihombing, K. S., \& Rahardjo, S. N. (2014). Analisis Fraud Diamond Dalam Mendeteksi Financial Statement Fraud : Studi Empiris Pada Perusahaan Manufaktur Yang Terdaftar Di Bursa Efek Indonesia (Bei) Tahun 2010-2012. DIPONEGORO JOURNAL OF ACCOUNTING, 3(2), 657-668.

Skousen, C. J., Smith, K. R., \& Wright, C. J. (2009). Detecting and predicting financial statement fraud: The effectiveness of the fraud triangle and SAS No. 99. Advances in Financial Economics, 13(99), 53-81. https://doi.org/10.1108/S1569-3732(2009)0000013005

Summers, S. L., \& Sweeney, J. T. (1998). 1998 Fraudulently Misstated Financial Statements and Insider Trading copy.pdf. The Accounting Review, 73(1), 131-146. https://doi.org/DOI:

Suyono, E. (2017). Bebagai Model Pengukuran Earnings Management : Sustainable Competitive Advantage7 (Sca-7) Feb Unsoed, 7(September), 303-324. Retrieved from https://www.researchgate.net/profile/Eko_Suyono2/publication/321490082_Berbagai_Model_Pen gukuran_Earnings_Management_Mana_yang_Paling_Akurat/links/5a2793cea6fdcc8e866e792d/Ber bagai-Model-Pengukuran-Earnings-Management-Mana-yang-Paling-Akurat.pdf

Vermeer, T. (2003). The impact of SAS No. 82 on an auditor's tolerance of earnings management. Journal of Forensic Accounting, 3, 21-34.

Wolfe, D. T., \& Hermanson, D. R. (2004). The Fraud Diamond: Considering the Four Elements of Fraud. THE CPA Journal. https://doi.org/DOI:

Yusof, M., Khair, A., \& Simon, J. (2015). Fraudulent Financial Reporting: An Application of Fraud Models to Malaysian Public Listed Companies. The Macrotheme Review, 2(4), 144-160. 